\title{
反射型液晶ディスプレイに求められる明度と コントラストの条件
}

\author{
正会員窪 田 悟 ${ }^{\dagger}$

\section{Lightness and Contrast Requirements for Legibility of Reflective Liquid Crystal Displays}

\author{
Satoru Kubota ${ }^{\dagger}$
}

\begin{abstract}
The purpose of this study is to investigate the required lightness and contrast for legibility of reflective liquid crystal displays (LCDs) Thirty subjects rated 65 lightness and contrast combinations displayed on the hard copy that simulate a reflective LCD, under various ambient illuminance conditions The results indicate that a higher contrast ratio is required as the lightness $\mathrm{L} *$ of the background is decreased lower than 65 or 70 (i e reflectance is $35-40 \%$ ) The required contrast ratio is about 5 when the lightness is higher than 65 or 70 . The influence of ambient illuminance on subjective legibility of the simulated reflective LCDs is not so obvious when the lightness of the background is higher than 65 or 70 These results suggest that the lightness of the background should be higher than 65 or 70 , and the contrast ratio between the characters and background should be at least 5
\end{abstract}

\section{1. まえ がき}

反射型の液晶ディスプレイ（Liquid Crystal Display：LCD）は, 小型軽量, 低消費電力という利点 を備えており，携帯用の情報機器に欠くことができな い.しかし, 現状の反射型 LCD は, 画質という点で 透過型 LCD に及ばない1). 特に, 表示文字の視認性 を左右している明度とコントラストの向上は最重要課 題である.したがって, 反射型 LCD の明度およびコ ントラストと表示の読み取りやすさとの関係を明確に しておくことは, 反射型 LCD の開発にあたって不可
欠である。

透過型 LCDについては, 表示輝度, コントラス 卜，鏡面反射，視野角などの要因について，視覚特性 に即した開発指針を得るために，実験的な検討を重ね てきた ${ }^{2) \sim 4}$. しかし, 反射型 LCD は, 透過型 LCD や 自発光型ディスプレイのように能動的に光を発するデ イスプレイと基本的に異なる。したがって, 従来の透 過型 LCD を対象とした評価研究の知見は必ずしも適 用できない。むしろ印刷物のそれに近い。また，印刷 物の評価と同様の枠組みで考えると, 照明条件が重要 な要因となる.さらに, 反射型 LCD の理想的な表示

キーワード：液晶ディスプレイ，視認性，画質評価

1996 年 2 月 13 日受付, 1996 年 3 月 21 日再受付

†成蹊大学 工学部 (广 180 武蔵野市吉祥寺北町 3-3-1, TEL 0422-37-3772)

$\dagger$ Faculty of Engıneerıng, Seıkeı Unıversity (3-3-1, Kıchıoıı-kıtamachı, Musashıno-shı, Tokyo 180, Japan) 
条件を求めるためには，現状の反射型 LCD をもって しては設定できる条件の範囲に限りがあり，他の手段 によらなくてはならない。

平ら ${ }^{5)}$ は，印刷画像を用いた主観評価実験により反 射型 LCD に要求される反射率とコントラストの関係 について検討し，低明度条件ではより高いコントラス トが求められるなどの結果を得ている，ただし，照度 条件の影響, $\mathrm{LCD}$ 特有の色彩の影響については考慮 していない.

本研究では，まず，フルカラーのディジタルプリン 夕用いて，反射型 LCD をシミュレートしたハードコ ピーを作成した。そして，作成したハードコピーに対 する異なった照度条件における主観評価実験により， 反射型 LCD の文字画像に求められる明度とコントラ ストの条件について検討した。実験では, 文字背景の 明度, コントラスト, 文字背景の色, 照度の 4 要因が 表示文字の読み取りやすさに及涩す影響について総合 的に検討した.

なお，ハードコピーによって反射型 LCD の表示特 性をシミュレートすることの妥当性は, ハードコピー と同一の文字画像を表示した反射型 LCD に対する主 観評価の結果が, 同等の明度とコントラストのハード コピーのそれと一致することをもって検証した．

\section{2. 方法}

\section{1 評価対象}

パーソナルコンピュー夕（Macintosh Quadra 840 $\mathrm{AV} ＼mathrm{~ と ~} 3$ 機種のフルカラープリンタを用い，様々な 明度とコントラストの反射型液晶画面をシミュレート したハードコピーを作成した．文字部は，インクジェ ットプリンタ（Canon PIXEL-JET）とトナー式プリ ンタ（Xerox A-color 636）を用い，様々な濃度の無 彩色で OHP フィルムに出力した。これを昇華型プリ ンタ（Tektronix Phaser 440 JS）で作成した様々な 明度の文字背景に貼り付けた。文字背景の色は，無彩 色と一般的な STN-LCD の色 $\left(a^{*}=-13, b^{*}=6\right)$ の 2 条件とした。この方法によって, 反射型液晶画面の 質感に近い様々な明度とコントラストの文字画像を作 成した。評価画面を図 1 に示す，印字した文字のサイ ズは 12 ポイント，書体は中ゴシックとした．文字間 隔は約 $0.5 \mathrm{~mm}$, 行間隔は約 $3 \mathrm{~mm}$ であった。この画 面は A 4 用紙の中央に印刷されている。画面周囲の 枠は明度 $L^{*}=58$ （反射率 $27 \%$ ）のグレイにした。

\section{2 実験条件}

表示条件を図 2 に示した。すなわち，（1）文字背景 の明度条件を 6 条件，（2）文字背景の色を 2 条件, 無

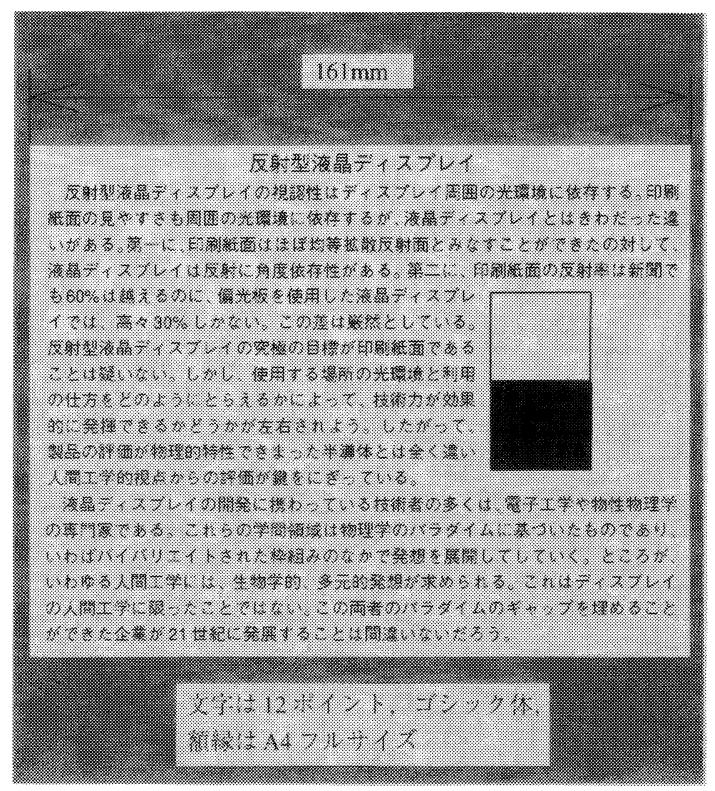

図 1 主観評価実験に使用したハードコピー画面 Hard copy display used in the experiment.

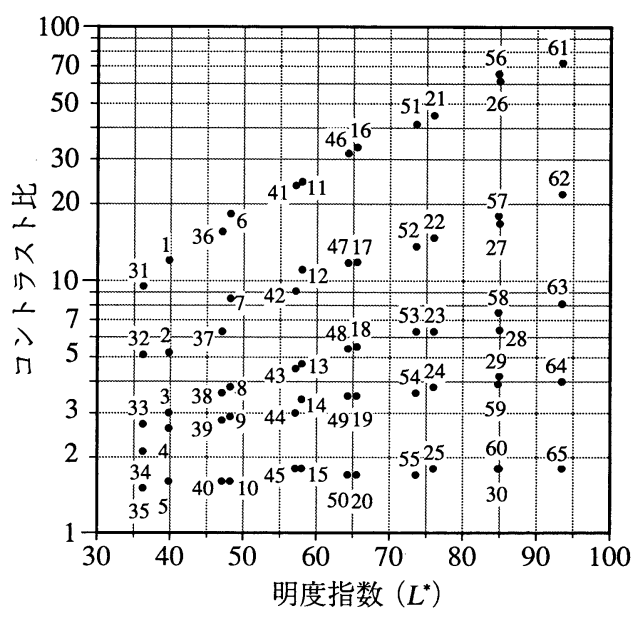

図 2 実験で設定した明度とコントラストの条件 (1〜 65 は条件番号を示す. 1 30 は STNLCD 色, 31 65 は無彩色)

Lightness and contrast combinations employed in the experiment.

彩色とSTN 反射型液晶に合わせた色，(3) 文字部の 明度を 5 条件, 以上の合計 $(6 \times 2 \times 5)=60$ 条件に, 背景が白紙 $\left(L^{*}=94\right)$ に対して文字部の明度 5 条件, 合計 65 条件である。また，照度の影響を評価するた めに, 机上面照度 $70,300,1200 \mathrm{~lx}$ の 3 条件について 実験した。照明条件は，色比較用 $\mathrm{D}_{65}$ 蛍光ランプの天 井照明を調光して設定した。評価対象は机上面に水平 
に置いた。これを天井照明が映り込まないように, 約 $45^{\circ}$ の角度から視距離約 $30 \mathrm{~cm}$ で観察させた. 実験室 には空がない。壁面は無彩色に近く反射率は約 $60 \%$ であった。

各条件の反射率は, $\mathrm{D}_{65}$ 蛍光ランプを評価対象に対 して $45^{\circ}$ の入射角に設置して, 法線方向から輝度計 （TOPCON BM-5 A）で反射輝度を測定し, 標準白 色板 $\left(\mathrm{BaSO}_{4}\right)$ の反射輝度との比から求めた. この值 は実験の観視条件における值に一致する。明度は反射 率に対応した心理物理量である. 本研究では CIE $1976 L^{*} a^{*} b^{*}$ 色空間による明度指数 (Psychometric lightness： $\left.L^{*}\right)$ を用いた。明度指数 $\left(L^{*}\right)$ と反射率 $(\rho)$ との関係は， $L^{*}=116 \rho^{1 / 3}-16$ によって表される。 な お, コントラストは, 背景部の反射率/文字部の反射 率とする。

\section{3 被験者}

被験者は年齢 $20 \sim 25$ 歳の大学生男子 25 名, 女子 5 名, 合計 30 名であった. 視力は, $0.2 \sim 1.5$ (矯正含 む）で，いずれの被験者も色覚は正常であった。

\section{4 手続き}

被験者は, あらかじめディスプレイのコントラスト と明度の概念および評定尺度法について, 実験者から 30 分間程度の講義を受けた。その後, ひとりずつ, 65 (表示条件) $\times 3$ (照度条件) $=195$ 条件について文 字の読み取りやすさを主観評価した。評価尺度は次の と抢りであった。

1 : 非常に読み取りにくい（ディスプレイとして全 く使えない)，2：読み取りにくい（ディスプレイとし て使いたくない，3：やや読み取りにくい（ディスプ レイとして普通に使える限界)，4：普通に読み取れる (ディスプレイとして問題なく使える)，5：やや読み 取りやすい，6：読み取りやすい，7：非常に読み取り やすい,である。括弧内の表現は, 実際の使用を想定 した評価尺度として, 被験者に示したものである。こ れを対応づけて応答するように指示した。

条件は順序効果を相殺するためにランダムに提示し た。各条件は 1 回ずつ評価させた。 65 の画面条件を 終えたら，照度を変えて試行を繰り返す．照度条件を 切り替えた際に順応時間を約 5 分間おいた。実験時間 は約 1 時間であった。

図 3 明度とコントラストに対する主観的な読み取り やすさ (無彩色条件)

Subjective legibility as a function of lightness and contrast for the reflective display with achromatic color. (a ) $70 \mathrm{~lx}$, ( b ) $300 \mathrm{~lx}$, (c ) $1200 \mathrm{~lx}$.

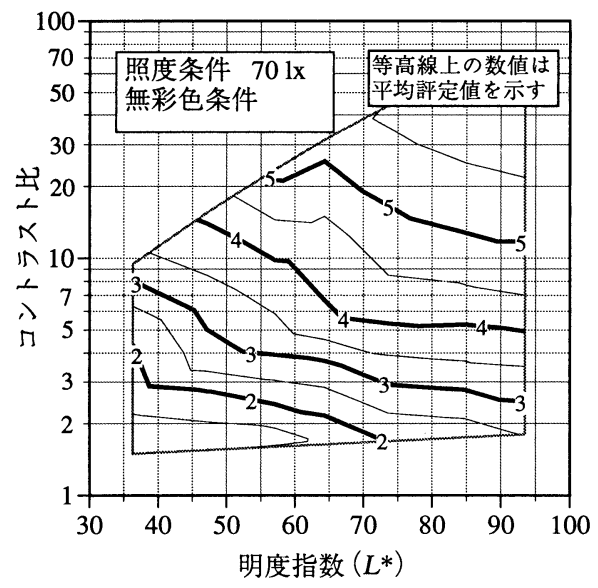

(a) $701 x$ 条件

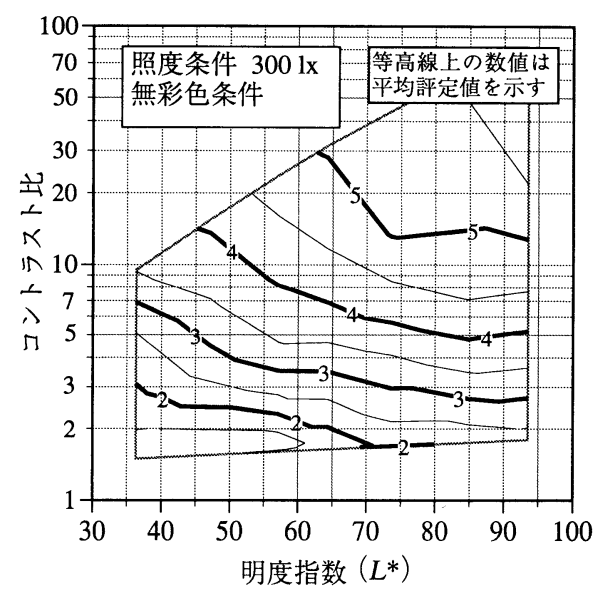

(b) $300 \mathrm{~lx}$ 条件

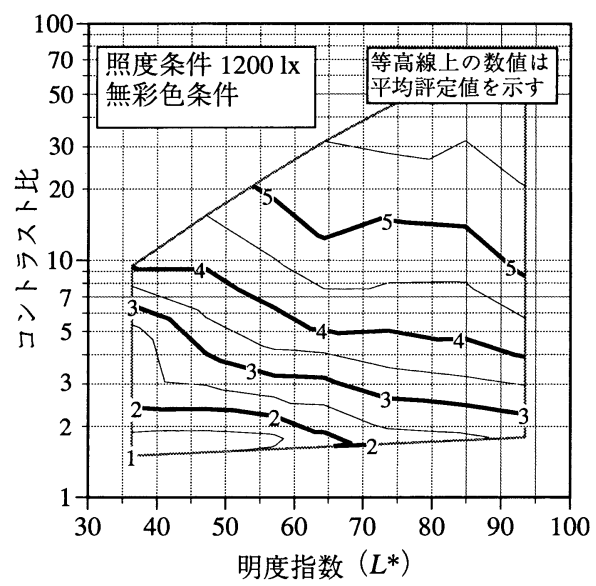

(c) $1200 \mathrm{~lx}$ 条件

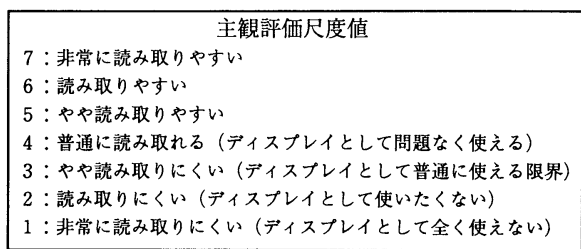




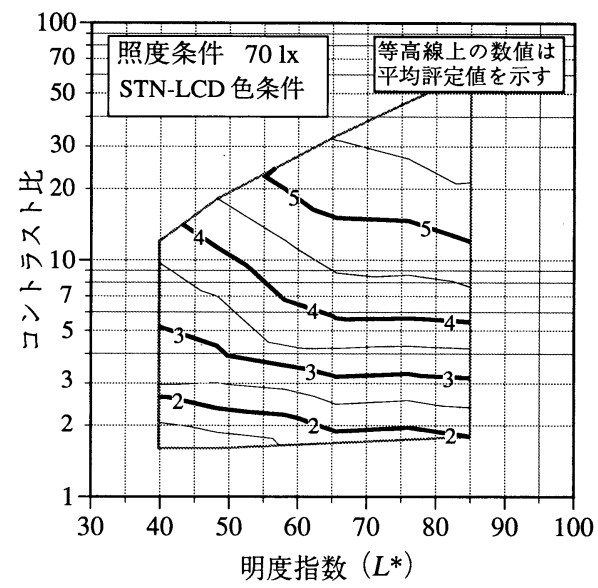

(a) $70 \mathrm{~lx}$ 条件

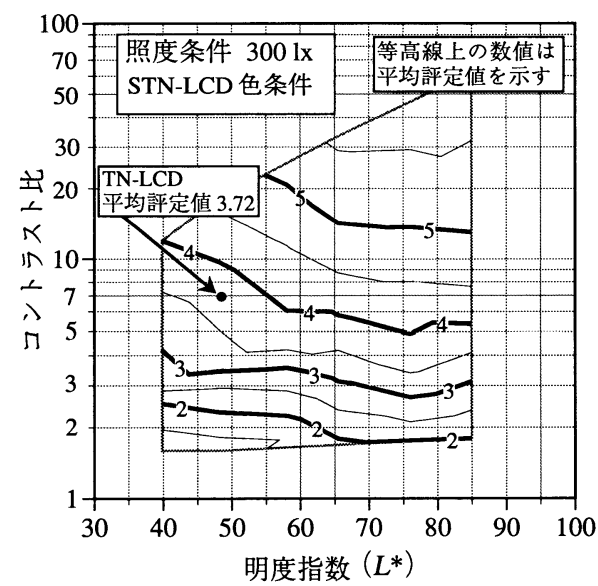

(b) $300 \mathrm{~lx}$ 条件

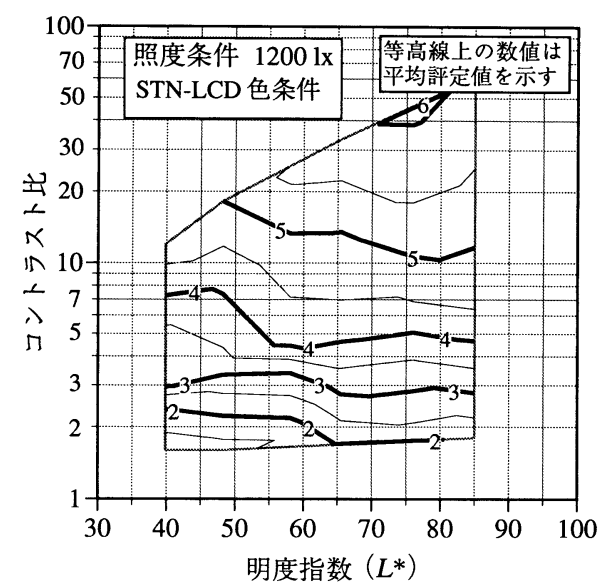

(c) $12001 \mathrm{x}$ 条件

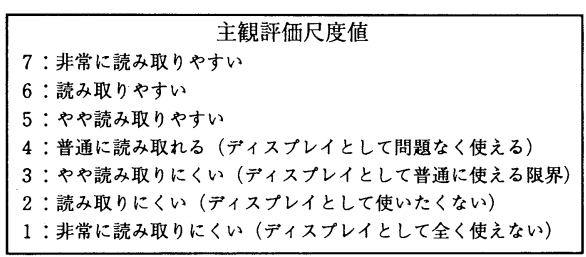

2.5 反射型 LCD の表示特性をハードコピーで代 用することの妥当性の検討実験

ハードコピーによって反射型 LCD の表示特性をシ ミュレートすることの妥当性について検討した。すな わち，ハードコピーと同一の文字画像を表示した反射 型 LCD に対する主観評価実験を行った。そして，同 等の明度とコントラストのハードコピーの評価結果と 一致することを確認した。用いた反射型 LCD は, TN-LCD (スタティック駆動)で，実験に使用した八 ードコピーと同一の文字列を表示した，ただし，表示 文字の書体だけはハードコピーのゴシック体と異なり 明朝体であった。その他, 表示書式, 文字サイズ, 額 縁明度などは，ハードコピーと一致させた．

主観評価の方法は，ハードコピーによる実験に準じ た。水平面照度は $300 \mathrm{~lx}$ とした。㴬型 LCD の表示 特性は, $300 \mathrm{~lx}$ の実際の観視条件において, $L *=48$, $a *=-3.8, b *=9.3$, コントラスト比 6.9 であった. 被験者は, $22 \sim 30$ 歳の大学生男子 24 名, 女子 6 名, 合計 30 名であった。各被験者は, 実験室の照度レべ ルに順応した後, 先に示した主観評価尺度で反射型 LCD の表示文字の読み取りやすさを評価した。各被 験者 1 回の評価を 30 名の被験者で集計して平均值を 求めた.

\section{3. 結果と考察}

ハードコピーに対する主観評価の結果は，各条件に 対する 30 名の平均評定值を求め, 明度とコントラス トに対して，等評価尺度を与える曲線で表現した。無 彩色条件（図 3）とSTN-LCD 色条件（図 4）に分け て, 照度条件ごとにプロットした。評定值の被験者間 のばらつきは，標準偏差で 1 前後であった。

実際の反射型 LCD に対する評価結果は図 4(b) に 表示した. 30 名の平均評定值は 3.72 , 標準偏差 1.14 であった。1機種だけではあるが, 実際の反射型 LCD に対する評価が同等の明度とコントラストのハ ードコピーに対する評価とほぼ一致している。したが つて，ハードコピーに対する主観評価実験の結果をプ ロットした図 3 と図 4 から, 反射型 LCD の明度とコ ントラストが読み取りやすさに及ほす影響を予測でき るといえよう。

図 4 明度とコントラストに対する主観的な読み取り やすさ（STN-LCD 色条件）

Subjective legibility as a function of lightness and contrast for the reflective display with the color of a typical monochrome STN-LCD. (a) $70 \mathrm{~lx}$, (b) $300 \mathrm{~lx}$, (c) $1200 \mathrm{~lx}$. 
ハードコピーに対する主観評価実験の結果は，次の ようにまとめられる。

（1）明度指数 65～70(反射率 35～40\%) 以下の条 件では, 明度が下がるほど, 同レベルの読み取 りやすさを確保するために，より高コントラス トが求められる.

（2）明度指数 $65 \sim 70$ 以上では, 読み取りやすさ は，ほぼコントラスト比のみに依存している。

（3）明度指数が $65 \sim 70$ 以上では，コントラスト 比が約 5 で評定值 4 のディスプレイとして問題 なく使用できるレベル，コントラスト比約 3 で 評定值 3 のディスプレイとして普通に使える限 界条件になる。

（4）明度が低い条件で, 照度の影響が認められ る.すなわち, 明度指数が $65 \sim 70$ 以下の条件 では, 照度が高いほど読み取りやすさの評価が 高い. 特に $1200 \mathrm{~lx}$ 条件での低明度域の読み取 りやすさの向上が顕著である.

（5）低明度条件では，STN-LCD 色条件の方が 無彩色条件よりも評価が高く, 逆に, 高明度条 件では, 無彩色条件の方が STN-LCD 色条件 より評価が高い。これは, 低明度では無彩色よ りも有彩色の方が等明度でも明るさ感が高いこ とが影響しているものと考えられる。

（6）新聞紙面は, 明度指数 $75 \sim 80$, コントラス 卜比 5～6であるから, 読み取りやすさの評価 は，おおむね評定值 4 のディスプレイとして問 題なく使えるに相当する. 比較的高コントラス トのコピー紙面は, 明度指数約 90 , コントラ スト比 10〜15であるから, 読み取りやすさの 評価はおおむね評定值 5 のやや読み取りやすい に相当する。

以上の結果を総合すると, 視覚特性に即した反射型 LCDの開発目標は, 明度指数 $65 \sim 70$, 反射率で 35〜 40\%，コントラスト比約 5 にあると考えられる. なぜならば, 明度指数が $65 ７ 0$ を越えると, 読み取 りやすさは，ほぼコントラストのみに依存し，かつ， 照度の影響を受けにくいという結果が得られている。 また，この明度条件に対して，コントラスト比約 5 で 評定值 4 のディスプレイとして問題なく使えるという 評価が得られる。さらに，この読み取りやすさの評価 レベルは, 新聞紙面（明度指数 $75 \sim 80$, 反射率で 50 〜 $60 \%$ ，コントラスト比 5〜6) に匹敵する.
ちなみに，市場で入手できる反射型 STN-LCD の 明度指数は, 実際の使用環境下で $30 \sim 60$, 反射率で 6〜30\%，コントラスト比 3〜6である.

\section{4. むす び}

反射型 LCD に文字画像を表示する場合に要求され る明度とコントラストの条件を, 反射型 LCD をシミ ュレートしたハードコピーに対する主観評価実験によ り検討した。主な結果は次の通りである。

（1）明度指数 65～70（反射率 35～40\%）以下の 条件では，明度が下がるほど，高コントラスト が求められる.

（2）明度指数が $65 \sim 70$ 以上の条件では，コント ラスト比が約 5 で,ディスプレイとして問題な く使用できるレベルになる

（3）明度指数 $65 \sim 70$ 以上の条件では，照度が読 み取りやすさに及ぼす影響は比較的小さい。

これらの結果より，視覚特性に即した反射型 LCD の開発目標を，明度指数 65〜 70, 反射率で 35〜 40\%, コントラスト比約 5 とした。この条件の読み取りやす さは，新聞紙面の読み取りやすさに匹敵することを示 した.

なお，本研究では，表示の観視角依存性や反射板と 液晶層の視差の要因は排除した条件で実験した。これ らの要因が表示文字の視認性に及ぼす影響については 現在検討中である.

\section{〔参 考 文 献〕}

1）窪田：“平面ディスプレイの人間工学的要件”, 照学誌, 76,10 , pp. 549-556 (Oct. 1992)

2）窪田：“透過型液晶ディスプレイに求められる表示輝度とコ ントラストの条件”,テレビ誌, 50, 6, pp. 768-774(June 1996)

3）窪田：“液晶ディスプレイの反射特性と反射グレアの関係”, 照学誌, 79, 5, pp. 226-223 (May 1995)

4）篗田：“液晶ディスプレイの視野角の評価”, テレビ誌, $\mathbf{4 6}, 3$, pp. 354-356 (Mar. 1992)

5）平, 鈴木: “反射型 LCD に要求される反射率・コントラスト の関係一印刷画像を用いた主観評価及び解析一”,テレビ学 技報, 20, 9, pp. 113-118(Feb. 1996)

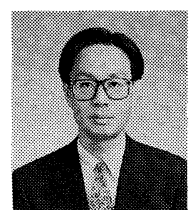

㕠苗悟 1976 年, 成蹊大学工学部経 営工学科卒業. 現在, 同大助手. 電子ディス プレイのヒューマンファクタに関する研究に 従事. (財) 労働科学研究所協力研究員. 博 士 (工学). 正会員. 